\title{
Trouncing Noogenic Neuroses through Logos: a Logotherapeutic Reading of Paul Auster's The Brooklyn Follies
}

\author{
Avijit Pramanik ${ }^{1} \&$ Arindam Modak ${ }^{2}$ \\ ${ }^{1}$ Assistant Professor (W.B.E.S.), Department of Humanities and Social Sciences, Purulia \\ Government Engineering College, Purulia, West Bengal, India. \\ Email: apmanikgo@gmail.com \\ ${ }^{2}$ Assistant Professor, Department of Humanities and Social Sciences, National Institute of \\ Technology Durgapur, Durgapur, West Bengal, India. Email ID: arindam_m@yahoo.com
}

Received April 11, 2017; Revised July 12, 2017; Accepted July 15, 2017; Published August 11, 2017.

\begin{abstract}
The Third Viennese School of Psychotherapy, as Viktor E. Frankl's Logotherapy is commonly hailed, veers around the proposition that the primary motivational force of human existence is neither 'will to pleasure' as propounded by Psychoanalysis nor 'will to power' of Adlerian concept but a sheer 'will to meaning'. Logotherapy encapsulates the Greek word 'logos' in the sense of meaning, thus making itself a meaningcentred therapy to cure neuroses. Frankl quite sagaciously creates an ontological hiatus between noogenic neuroses and somatogenic neuroses declaring the former an offshoot of lack of meaning in life. Logotherapy aims to unlock the will to meaning and to assist the patient in seeing a meaning in his life under any miserable condition. This paper seeks to read Paul Auster's novel The Brooklyn Follies in juxtaposition with the fundamental aspects of Logotherapy to discover the journey of the characters from noogenic neuroses to amiable social existence, from dark pessimism to bright optimism, from solipsistic life to family life, and from existential vacuum to richness of survival.
\end{abstract}

Key-words: Logotherapy, Noogenic Neuroses, Homeostasis, Noo-dynamics, Existential Vacuum.

A Holocaust survivor and Professor of Neurology and Psychiatry at the University of Vienna Medical School, Viktor Emile Frankl stormed the whole world with his idea of Logotherapy, which is far different in nature and form from Freudian Psychoanalysis and Adlerian Individual Psychology. The Third Viennese School of Psychotherapy, as Logotherapy is commonly hailed, veers around the proposition that the primary motivational force of human existence is neither 'will to pleasure' as propounded by Psychoanalysis nor 'will to power' of Adlerian concept but a sheer 'will to meaning. ${ }^{\text {i }}$ Logotherapy encapsulates the Greek word 'logos' in the sense of meaning, thus making itself a meaning-centred therapy to cure neuroses. Frankl quite sagaciously creates an ontological distinction between noogenic neuroses and somatogenic neuroses declaring the former an offshoot of lack of meaning in life. Noogenic neuroses do not emerge from the battleground of multitudinous drives and instincts but from a frustrated 'will to meaning'. Psychotherapy is hardly applicable and effective for curing noogenic neuroses, which demands logos for extinguishing existential frustration and motivating the depression to achieve a new goal. Psychotherapy merely tranquillizes the patient suffering from noogenic cases by burying his existential despair and urge for a true meaning in life. Logotherapy is the apposite treatment

(C) AesthetixMS 2016. This Open Access article is published under a Creative Commons Attribution Non-Commercial 4.0 International License (http://creativecommons.org/licenses/by-nc/4.0/), which permits non-commercial re-use, distribution, and reproduction in any medium, provided the original work is properly cited. For citation use the DOI. For commercial re-use, please contact editor@rupkatha.com. 
which dares to delve deep into the human dimension of the patient and cures his 'existential distress', a sheer concern of man over the worthwhileness of life, rather than suppressing it under some tranquilizing drugs. Though the meaning of life constantly changes from time to time, it can be found according to Logotherapy in three different but interrelated ways: (1) by inventing a work or doing a deed; (2) by experiencing something or encountering someone; and (3) by the attitude one takes toward the unavoidable suffering. According to Frankl, logotherapy aims to unlock the will to meaning and to assist the patient in seeing a meaning in his life under any miserable condition:

The logotherapist's role consists of widening and broadening the visual field of the patient so that the whole spectrum of potential meaning becomes conscious and visible to him. (Man's Search for Meaning, 115)

Though Logotherapy is a medical treatment for curing neuroses, its doctrines based not on any medicines but on showing avenues to discover meaning in life are adequate to interpret and deconstruct literary texts which are the sites of iridescent human behaviour and the battlegrounds for multifarious human emotions. To understand the trajectory of emotions of the literary characters - their conflicts and dynamics - the tenets of Logotherapy will be of immense help and will enable a discerning reader to shed light on some unexplored issues in the given text. This paper seeks to read Paul Auster's novel The Brooklyn Follies in juxtaposition with the fundamental aspects of Logotherapy to discover the journey of the characters from noogenic neuroses to amiable social existence, from dark pessimism to bright optimism, from solipsistic life to family life, and from existential vacuum to richness of survival. The traditional criticism of Paul Auster's writings has focussed mainly on his experiments with postmodernity and his connection with the French existentialists. Significantly and quite mysteriously, there is a dearth of psychological interpretation of Auster's works. Auster's novels are a prominent site of psychological analysis as: "Auster's literature is centrally concerned with how we, as individuals, live collectively" (Brown, 1). I have sought to explore this symbiotic relationship between individual and collective living of Auster's fictional characters from the theoretical angle of Frankl's logotherapy which is a meaning-oriented approach to psychotherapy and is "characteristically different from other treatment modalities, in that it starts with the essence of life, and it is concerned with the whole and purpose of life" (Marshall, 8). As leading a meaningful and purposeful life is at the centre of logotherapy, it is apt for interpreting Auster's novels which veer around human relationships and the impact of those relationships on individual as well as collective living. I hope this study will augment the application of Frankl's theoretical postulates in explicating literary texts in general, and provide the much needed impetus to the psychological interpretation of Auster's novels, in particular.

One of the champions of postmodern literature, Paul Auster has marked a niche of his own and has become "one of the most prolific, critically acclaimed, and intensely studied of living American writers" (Hutchisson, XI). Auster's writing style and content of his works can hardly be subsumed under the nomenclature of any 'school' of literary practice. Auster has done the rare feat of drawing the attention of the literary critics and the reading laymen alike. However, his works have polarised the critics. While Critics like Dennis Barone and Harold Bloom have lavishly showered accolades upon Paul Auster, Eric Wirth has severely chastised his mode of writing. According to Wirth, Auster is a writer who "admits clichéd formulas of melodrama" and his "predilection for artless language reaches to hackneyed figures of speech" (Beyond the Red Notebook, 176). But this sort of adverse criticism does not deter critics like Aliki Varvogli and Dennis Barone from comparing Auster with classic writers like Kafka (Varvogli, 109) and 
Nathaniel Hawthorne (Barone, 1). When Harold Bloom thinks "aesthetic dignity is the keynote of everything I have read by Auster"(Paul Auster,1), Dennis Barone takes Auster as "a writer willing and daring enough to probe the depths of a horrible despair one moment and tell a joke-perhaps at his own expense-the next" (Beyond the Red Notebook, 3). The fundamental concern of Auster's novels lies in explicating human identity and existential crisis. His novels are also replete with materials of detective fiction and picaresque novels. Aliki Varvogli has discerned in Auster's works a fruitful combination of "metafictive elements with a clearly articulated interest in, and engagement with, the contemporary world" (The World, 2). Somewhat in the same vein, Bernd Herzogenrath in his book An Art of Desire has pointed: "Auster's novels, being investigations into the 'art of desire', reveal the chiastic relationship of 'life' and 'text' centred around an enigmatic, constitutive lack" (11). Any discerning reader of Auster's novels can also easily note the theme of survival flowing through his works. His characters fight arduously to bring their lives back to effervescent and fruitful life out of the nadir of extinction and optimal disappointment. This present paper, within its small ambit, has tried to discern this essence of survival in Auster's much celebrated novel The Brooklyn Follies in the light of Frankl's logotherapy. Frankl in his seminal book The Doctor and the Soul has talked of three principles or 'values'-creative values, experiential values, and attitudinal values ${ }^{\mathrm{ii}}$-adhering to which can proffer meaning to life. This present study has been carried out by keeping these three fundamental principles of logotherapy as the theoretical scaffolding.

Auster's The Brooklyn Follies, which has been termed as "a violent return of socio-political reality into Auster's fictional universe” (Theobald, 251), is a novel on human relationship and celebrates the talismanic power of love to save a man from falling prey to existential anxiety and frustration. Being denuded of his health, work, and wife, Nathan Glass, a cancer survivor, loses the urge for survival and merely craves "a silent end to my sad and ridiculous life" (1). As he was looking for "a quiet place to die" (1), he comes to Brooklyn to lead a solitary life and embrace death silently. We can easily discern that Nathan's 'will to meaning' has been disrupted and he considers his life to be a meaningless existence:

I had given myself up for dead, once the tumour had been cut out of me and I'd gone through the debilitating ordeals of radiation treatment and chemo, once I'd suffered the long bouts of nausea and dizziness, the loss of hair, the loss of will, the loss of job, the loss of wife, it was difficult for me to imagine how to go on. (3)

At this critical juncture, Nathan decides to engage himself in writing a book called The Book of Human Folly by the dint of which he can fill the existential vacuum of his life. Though he has been denied of a normal family life of peace and quiet, even at the age of sixty Nathan challenges 'homeostasis' and prepares himself for 'noo-dynamics'. According to Viktor E. Frankl, human being scarcely requires 'homeostasis' that is a tensionless state to exist in this world. Rather, he needs striving to achieve a worthwhile goal and to accomplish a voluntarily chosen goal. Frankl postulates the verdict: "What man needs is not homeostasis but what I call 'noo-dynamics', i.e., the existential dynamics in a polar field of tension where one pole is represented by a meaning that is to be fulfilled and other pole by the man who has to fulfil it" (Man's Search for Meaning, 110). As soon as Nathan starts writing the book, he enables himself to take part in the noodynamics of his existence. Writing, to Nathan, appears to be a convenient tool to overcome the pulverizing effect of existential vacuum. Noo-dynamics keeps human beings oriented towards concrete values to be actualised and towards the meaning of our personal existence to be fulfilled. Engaging himself in a creative work like authoring a book, Nathan discovers a meaning to be fulfilled and a goal to be accomplished in life. As the confessed motive behind writing the book is 
"to keep myself entertained while using up as many hours of the day as I could" (6), Nathan explicitly follows logotherapy's first principle of discovering meaning in life "by creating a work or doing a deed"(Man's Search for Meaning, 115) as expounded by Frankl. Nathan's chasing after a concrete meaning through writing a book also keeps his death instinct at bay. In his seminal essay Foucault has observed that our culture tends to look at writing as a means of survival: "Our culture has metamorphosed this idea of narrative, or writing, as something to ward off death" (206). Like a typical Austerian hero, Nathan seeks to reconnect his alienated self with the external world through writing. Mark Brown has sagaciously commented: "Storytelling in Auster's work functions as a means by which the alienated individual can share with others, and reconnect to the social realm" (Paul Auster, 4).Writing of past experiences gives Nathan an opportunity to relive the past with the added benefit of lulling the present distress.

During his solipsistic life in Brooklyn, Nathan fortuitously meets his nephew Tom Wood. Though he had been an extraordinary scholar with a four-year fellowship to complete his PhD dissertation on pre-civil war mindset of the Americans with a special focus on the literary works of Poe and Thoreau, he is now working in a second-hand bookstore in Brooklyn. He had undergone strenuous ordeals in life as he had left the thesis incomplete in the middle and worked as a taxi-driver. Losing his family members and fellowship, Tom is a lonely human being without any meaning in life just like his uncle Nathan. What is significant about Tom is that he never grumbles over his present situation. He asserts: “I want to live in a new way, that's all. If I can't change the world, then at least I can try to change myself" (107). Tom is visibly following logotherapy's third principle of discovering meaning in life "by the attitude we take toward unavoidable suffering" (Man's Search for Meaning, 115). Tom is not morose with the invidious incidents which have dismantled his smooth life and distracted him from his academic uplift as he has found meaning in bearing the unavoidable conditions of his life. He considers this ordeal as an opportunity to mould his character in a stronger way. Viktor E. Frankl has succinctly encapsulated this sort of attitude to life in his celebrated book Man's Search for Meaning:

We must never forget that we may also find meaning in life even when confronted with a hopeless situation, when facing a fate that cannot be changed. For what then matters is to bear witness to the uniquely human potential at its best, which is to transform a personal tragedy into a triumph, to turn one's predicament into a human achievement. When we are no longer able to change a situation-just think of an incurable disease such as inoperable cancer-we are challenged to change ourselves. (116)

The motif of human companionship, be it love or friendship, flowing like an undercurrent all through the novel integrates the characters as well as the novel providing an astute critic a scope to delve deep into the hearts of the characters to cull out their search for meaning from the point of view of logotherapy. According to Frankl, meaning in life can be found by 'encountering someone' (Man's Search for Meaning, 115). Being cut off from their respective families, Nathan and his nephew, Tom both seek to derive console from their meetings and talks: "We both lived alone, neither one of us was involved with a woman and neither one of us had many friends"(81). Nathan makes it a ritual to take lunch with Tom and his conversations with Tom not only enable him to overcome his own anxiety about life but also draw him more closer to Tom's personal life, making him completely involved in his life. He comes to know about Tom's infatuation for Nancy, the BPM or Beautiful Perfect Mother and his concern for his sister Aurora who had met him to invite for her marriage but then disappeared. Gradually the lonely old man gets drawn towards family life. Here it would be quite apt to discuss Frankl's concept of responsibility. According to Frankl, logotherapy sees in taking responsibility, the very essence of human existence: "the 
humanness of man is grounded in his sense of responsibility" (Man's Search for Ultimate Meaning, 113). Logotherapy seeks to make the patient aware of his responsibility for someone or something:

Logotherapy can only heighten the patient's innate awareness of his responsibility, and this responsibility includes answering the question of how to interpret his life, that is to say whether along the lines of theism or atheism (Man's Search for Ultimate Meaning, 114).

Being isolated from his wife and daughter, Nathan forfeited his sensibility to become responsible for someone and consequently, he lost the meaning of life as well as the urge for life. Now, after meeting with Tom, Nathan becomes responsible to him. In the course of the novel, we discern that Nathan comes very close to his niece Aurora and Nancy's mother Joyce who confide their secrets to him making Nathan responsible to them. Nathan very honestly confesses:

Me. The bitter, solitary man who had crept home to Brooklyn less than a year earlier, the burnout who had convinced himself there was nothing left to live for-knuckleheaded me, Nathan the Unwise, who could think of nothing better to do than quietly wait to drop dead, now transformed into a confidant and a counsellor. (286)

Nathan was haunted by the experience of his inner emptiness and lack of worthwhileness due to his disease, divorce with wife, and increasing distance with daughter. This vacuum evaporated his desire for living. However, Nathan comes back to the rhythm of life and embraces optimism only when he becomes a responsible person. Frankl has argued: "Responsibleness has two intentional referents. It refers to a meaning for whose fulfilment we are responsible, and also to being before whom we are responsible" (The Will to Meaning, 31). With the dawning of responsibility to Tom, Aurora, and Joyce, Nathan finds meaning as well as a new direction in life.

Tom finds a direction in life when he meets Honey. Started with a fling, Honey proposes marriage which Tom taciturnly accepts. However, after the marriage Tom undergoes a seismic change. He finds the love he needed much to come out of his inertia and existential vacuum. Nathan comments: "It did me good to see how the slothful, bovine Tom flourished under the energetic influence of his newfound wife" (242). Tom's condition can be interpreted from the point of view of Frankl's idea of 'self transcendence of human existence' which veers round the fact that being human is to being committed to something or someone beyond his own self:

Thus, human existence-at least as long as it has not been neurotically distorted-is always directed to something, or someone, other than itself, be it a meaning to fulfil or another human being to encounter lovingly. I have termed this constitutive characteristic of human existence 'self-transcendence.' What is called 'self-actualization' is ultimately an effect, the unintentional by-product, of self-transcendence.” (Man's Search for Ultimate Meaning, 78)

The more one can forget oneself-by yielding himself to a work to complete or another person to love-the more human he is and more he can actualize himself. Self-actualization is not a goal in itself, rather it can be achieved through self-transcendence. According to Frankl, love is the only way to grasp another human being in the innermost core of his personality. No one can perceive the true essence of another person without loving him. It is his love which enables him to see the essential traits and possibilities of the beloved person which have not yet been actualized by that person. The lover helps the beloved to actualize his potentials by making him aware of his own qualities. Here in this novel, Honey first loves Tom, understands his potentials and enables him to realize his possibilities and then leads him to actualize them. Though before marriage Tom was in dilemma regarding the inherited property of Harry, his marriage turned him to be more 
responsible and "Within days of Honey's arrival, he ceased dithering about what to do with the inheritance and decided to put the building on the market" (242). With this pragmatic attitude Tom also revived his ambition to become a teacher. Losing his weight by twenty pounds Tom looked like his previous scholarly self. This episode of losing weight connotes Tom's waking from lethargy as well as despair. Consequently, relinquishing the book business to uncle Nathan, Tom prepares himself for a private school job for the next academic year. Tom had overlooked his possibilities which he can actualize now under the loving care of his beloved: "Day by day, she slowly turned him into the man he was always destined to become" (242).

Another very significant character in the novel, Harry, the owner of the second hand bookstore where Tom works, is a lonely person too and deserves analysis from the point of view of logotherapy. Harry had married Bette Dombrowski and opened an art gallery in Chicago. He used to promote the struggling and emerging painters. Once he exhibited the paintings of Alec Smith in his gallery and successfully drew the attention of huge crowd. From then on, Alec used to showcase all of his paintings at Harry's gallery. After Alec's sudden premature death, Harry forged his paintings with the help of another young painter and his homosexual love interest Gordon Dryer. Harry's forgery had been unmasked by Alec's wife and consequently, he had been sentenced. With this punishment, Harry lost his wife and daughter as well. Betty lodged a divorce case and her father made sure in terms of money that Harry would not contact them upon his release from jail. Upon his release from jail, he started the bookstore in Brooklyn and continued to live unruffled until his former lover Gordon Dryer had come to ruin his career leading him to death. What is significant about Harry is that he has not lost the urge for life, in other words the meaning of life or the will to meaning, despite losing his family, occupation and social status. He has accomplished to go beyond his guilty past rather than brooding on the bygone days. Nathan has aptly recognized this attitude of Harry towards life and appreciates this quality enthusiastically:

I am talking about the instinct for survival, Tom, the will to live. Give me a willy rascal over a pious sap any day of the week. He might not always play by the rules, but he's got the spirit. And when you find a man with spirit, there's still some hope for the world. (55)

In order to explain Harry's approach to life we must take recourse to the idea of 'tragic optimism' as proposed by Viktor E. Frankl. Tragic optimism refers to one's remaining optimistic in spite of the 'tragic triad' constituted of pain, guilt, and death. It is, in fact, a celebration of the human potential which can turn suffering into achievement, can derive the opportunity from guilt to metamorphose oneself for betterment of life, and can perform responsible actions to overcome the transience of life. A crime can hardly be explained away by referring to biological, psychological, and sociological factors because that would denude human being of his humanness and his freedom of choosing any action. One is as much responsible for committing a crime as he is responsible to overcome that guilt. Harry is happy in life as he has taken the initiative to go beyond his guilty conscience. He has found out his meaning in life by sticking to work and by showering love on his subordinate workers. After securing his release from jail, he could have pursued criminal activities. He did not do that. On the other hand, he had started a reputable book business and devoted his whole time for the betterment of his business. When he realizes that he might get trapped by Gordon, he makes a will which bestows his property on Rufus and Tom. It is through human love and sympathy, Harry finds a proper meaning in his life after his crime and forfeiting his family. He had to encounter one of the tragic triad-the guilt-which constitute our existence but he did not succumb to it. Rather, he had learnt lessons from his crime and sought his best to absolve himself. Rightly does Nathan remark: "All men contain 
several men inside them, and most of us bounce from one self to another without ever knowing who we are." (125)

The Brooklyn Follies explicitly evinces the journey of the protagonists from the depth of depression to the height of optimism. They unknowingly follow certain strategies which strictly conform to the tenets of logotherapy giving truth to the fact that human being is governed by a 'will-to-meaning' which may get disturbed for sometime but can be revived by a few changes in life as well as in attitude to life. Nathan, Tom, and Harry have proved that they can subdue any disappointment and can continue to proceed in life with the help of logotherapy. Interestingly, they do not visit the chamber of any logotherapist to discover meaning in life, rather they stick to a few deeds which happily coincide with the postulates of logotherapy.

\section{Notes}

i In Freudian psychoanalysis, the 'pleasure principle' is the instinctual seeking of pleasure and avoiding pain in order to satisfy biological and psychological needs. In Civilization and Its Discontents, Freud asserts: "what decides the purpose of life is simply the programme of pleasure principle" (23). Though the "will to power' is a popular concept in the philosophy of Friedrich Nietzsche, it has been incorporated into his individual psychology by Alfred Adler. According to Adler, the striving of the individual to overcome actual or felt inferiorities is the guiding force of an individual for survival: "The key to the social process is the fact that people are always striving to find a situation in which they can excel" (Understanding Life, 30). Frankl's logotherapy relegates the 'pleasure principle' and the 'power principle' to foreground 'logos' or meaning as the sole motivational force in man: "the Freudian pleasure principle is the guiding principle of the small child, the Adlerian power principle is that of the adolescent, and the will to meaning is the guiding principle of the mature adult" (The Will to Meaning, 25).

${ }^{\text {ii }}$ Creative values refer to our engagement in creative action and 'achievement of tasks' (Frankl, 1986; pp. xix) by using our talent to make and create something that did not exist before. We can actualize the experiential values "by experiencing the Good, the True, and the Beautiful, or by knowing one single human being in all his uniqueness" (Frankl, 1986; pp. xix). Attitudinal values, which do not require the ability to create, or to experience, indicate the "very attitude with which we face our unchangeable suffering" (Frankl, 1986, pp. xix).

\section{References}

Adler, A. (1997). Understanding Life. Oxford: Oneworld Publications.

Auster, P. (2006). The Brooklyn Follies. New York: Henry Holt and Company.

Barone, D. (1995). Introduction: Paul Auster and the Postmodern. In Barone (Ed.), Beyond The Red Notebook (pp. 1-26). Philadelphia: University of Philadelphia Press.

Bloom, H. (2004). Introduction. In Bloom (Ed.), Paul Auster (pp. 1-2). Philadelphia: Chelsea House Publishers.

Brown, M. (2007). Paul Auster. Manchester: Manchester University Press.

Foucault, M. (1998). What is an Author?. In J. D. Faubion (Ed.), Aesthetics, Method, and Epistemology (pp. 205-222). New York: The New Press.

Frankl, V. E. (1986). The Doctor and the Soul. New York: Vintage Books. 
---. (2008). Man's Search for Meaning. Great Britain: Rider.

---. (2012). Man's Search for Ultimate Meaning. New Delhi: MG Books.

---. (2014). The Will to Meaning. New York: Plume.

Freud, S. (1962). Civilization and Its Discontents (J. Strachey, Trans.). New York: Norton. (Original work published 1930)

Herzogenrath, B. (2005). An Art of Desire. Netherlands: Rodopi.

Hutchisson, J. M. (2013). Introduction. In Hutchisson (Ed.), Conversations with Paul Auster (pp. xi-xx). United States: University Press of Mississippi.

Marshall, M. (2011). Prism of Meaning. Retrieved from www.logotherapy.ca

Theobald, T. (2010). Existentialism and Baseball: the French Philosophical Roots of Paul Auster. Germany: LAP Lambert Academic Publishing.

Varvogli, A. (2001). The World that is the Book: Paul Auster's Fiction. Liverpool: Liverpool University Press.

Wirth, E. (1995). A Look Back from the Horizon. In Dennis Barone (Ed.), Beyond the Red Notebook (pp. 17182). Philadelphia: University of Philadelphia Press. 